\title{
Sorafenib tosylate inhibits directly necrosome complex formation and protects in mouse models of inflammation and tissue injury
}

Sofie Martens ${ }^{1,2}$, Manhyung Jeong ${ }^{3}$, Wulf Tonnus ${ }^{4}$, Friederike Feldmann ${ }^{5}$, Sam Hofmans ${ }^{6}$, Vera Goossens ${ }^{1,2}$, Nozomi Takahashi ${ }^{1,2}$, Jan Hinrich Bräsen ${ }^{7}$, Eun-Woo Lee ${ }^{8}$, Pieter Van der Veken ${ }^{6}$, Jurgen Joossens ${ }^{6}$, Koen Augustyns ${ }^{6}$, Simone Fulda ${ }^{5,9,10}$, Andreas Linkermann ${ }^{4}$, Jaewhan Song ${ }^{3}$ and Peter Vandenabeele ${ }^{*, 1,2}$

Necroptosis contributes to the pathophysiology of several inflammatory, infectious and degenerative disorders. TNF-induced necroptosis involves activation of the receptor-interacting protein kinases 1 and 3 (RIPK1/3) in a necrosome complex, eventually leading to the phosphorylation and relocation of mixed lineage kinase domain like protein (MLKL). Using a high-content screening of small compounds and FDA-approved drug libraries, we identified the anti-cancer drug Sorafenib tosylate as a potent inhibitor of TNF-dependent necroptosis. Interestingly, Sorafenib has a dual activity spectrum depending on its concentration. In murine and human cell lines it induces cell death, while at lower concentrations it inhibits necroptosis, without affecting NF- $k$ B activation. Pull down experiments with biotinylated Sorafenib show that it binds independently RIPK1, RIPK3 and MLKL. Moreover, it inhibits RIPK1 and RIPK3 kinase activity. In vivo Sorafenib protects against TNF-induced systemic inflammatory response syndrome (SIRS) and renal ischemia-reperfusion injury (IRI). Altogether, we show that Sorafenib can, next to the reported Braf/Mek/Erk and VEGFR pathways, also target the necroptotic pathway and that it can protect in an acute inflammatory RIPK1/3-mediated pathology.

Cell Death and Disease (2017) 8, e2904; doi:10.1038/cddis.2017.298; published online 29 June 2017

A delicate balance between cell death and proliferation is essential for tissue homeostasis in multicellular organisms. ${ }^{1,2}$ Disturbance of this balance underlies the pathogenesis of various diseases, such as inflammatory and degenerative diseases, infectious diseases and cancer. ${ }^{3}$ Necrotic cell death is characterized by swelling and bursting of the cell, thereby releasing cytokines, chemokines and damage-associated molecular pattern molecules (DAMPs), which in a concerted way propagate inflammation. ${ }^{4}$ The discovery of necroptosis as a programmed form of necrosis that is regulated by the signaling of receptor-interacting protein kinases 1 and 3 (RIPK1/3), ${ }^{5-9}$ allowed to envisage necroptosis as a druggable process. Necroptosis can be triggered by DNA damage, immune receptors, viruses or death receptors of the TNF superfamily, such as Fas receptor (FasR), TRAILR1/2 or death receptor 3 (DR3), ${ }^{2,4}$ but the best characterized is TNFR1induced necroptotic signaling. Upon stimulation with TNF, TNF receptor 1 (TNFR1) trimerizes ${ }^{10}$ and a membrane-associated protein complex (TNFR1 complex I) is formed. ${ }^{11}$ Ubiquitylation of RIPK1 in this survival signaling complex results in activation of the $I_{K B}$ kinase (IKK)-complex, ${ }^{12}$ which causes degradation of $I_{K} \mathrm{~B}-a$ and thus NF- $\kappa \mathrm{B}$ activation. When inhibitors of apoptosis (IAPS), TGF $\beta$ activated kinase-1
(TAK1) or inhibitor $\kappa$ B kinases (IKKs) are blocked, RIPK1 kinase is activated and results in RIPK1-dependent apoptosis or necroptosis. ${ }^{13}$ When caspase- 8 is inhibited ${ }^{14-16}$ or FADD is absent, ${ }^{17}$ the necrosome complex consisting of RIPK1 and RIPK3 is formed. Activated RIPK3 phosphorylates mixed lineage kinase domain like protein (MLKL), which relocates to the plasma membrane and directly ${ }^{18,19}$ or indirectly ${ }^{20,21}$ affects plasma membrane permeabilization. Necrostatins were the first identified inhibitors of necroptosis targeting RIPK1, ${ }^{5,22}$ but no necrostatin-like drugs have been reported to have reached preclinical development. We identified the FDAapproved Sorafenib tosylate (further referred to as Sorafenib) as a potent inhibitor of necroptosis in two independent screening assays using L929 cells. Sorafenib is a multikinase inhibitor that induces apoptosis of cancer cells ${ }^{23-25}$ and is clinically used to treat advanced hepatocellular carcinoma (HCC), advanced renal cell carcinoma, ${ }^{26}$ and acute myeloid leukemia $(\mathrm{AML}){ }^{27}$ Sorafenib exerts anti-tumor effects by inhibiting kinases involved in cell proliferation and survival. It inhibits tumor cell proliferation ${ }^{26,28}$ and angiogenesis ${ }^{26}$ through inhibition of Raf1 kinase ${ }^{29}$ and VEGFR1/2/3, PDGFRb, FGFR1 receptor tyrosine kinases ${ }^{29}$ respectively. Other cellular processes that are affected by Sorafenib are

\footnotetext{
${ }^{1}$ VIB-UGent Center for Inflammation Research (IRC), Ghent, Belgium; 'Department of Biomedical Molecular Biology (DBMB), Ghent University, Ghent, Belgium; ${ }^{3}$ Department of Biochemistry, College of Life Science and Biotechnology, Yonsei University, Seoul, Korea; ${ }^{4}$ Department of Internal Medicine III, Division of Nephrology, University Hospital Carl Gustav Carus at Technische Universität Dresden, Dresden, Germany; ${ }^{5}$ Institute for Experimental Cancer Research in Pediatrics, Goethe-University, Frankfurt, Germany; ${ }^{6}$ Laboratory of Medicinal Chemistry, University of Antwerp, Antwerp, Belgium; ${ }^{7}$ Department of Pathology, Hannover Medical School, Hannover, Germany; ${ }^{8}$ Metabolic Regulation Research Center, Korea Research Institute of Bioscience and Biotechnology (KRIBB), Daejeon, South Korea; ${ }^{9}$ German Cancer Research Center (DKFZ), Heidelberg, Germany and ${ }^{10}$ German Cancer Consortium (DKTK), Partner Site Frankfurt, Germany

${ }^{*}$ Corresponding author: V Peter, Department of Biomedical Molecular Biology, VIB, Ghent University, Technologiepark 927, Gent-Zwijnaarde, Ghent 9052, Belgium. Tel: +32 93 313720; Fax: +32 93 313609; E-mail: Peter.Vandenabeele@irc.vib-ugent.be

Received 10.5.17; Received 23.5.17; accepted 25.5.17; Edited by G Raschellà
} 
ER-stress mediated cell death independent of MEK and $\mathrm{ERK}^{30}$ and mTOR-mediated autophagy in HCC. ${ }^{31}$ It seems paradoxical that Sorafenib, a potent cytostatic and cytotoxic drug, inhibits necroptosis. We demonstrate that Sorafenib exerts this dual activity depending on its concentration. Furthermore, we show the inhibition of RIPK1 and RIPK3 as the mechanism underlying this novel function of Sorafenib.

\section{Results}

Compound screenings in cellular models of TNFmediated necroptosis identify Sorafenib as a potent necroptosis inhibitor. To identify novel inhibitors or regulators of necroptosis, 500 small compounds from libraries targeting autophagy, kinases, phosphatases, proteases and redox balance were screened for their ability to block TNF-induced necroptosis in murine L929sAhFas cells. Three conditions were used to induce necroptosis in L929 cells: TNF alone, TNF+TAK1 inhibitor (TAK1i) and TNF+ZVAD-fmk, a pan-caspase inhibitor. Inhibition of TAK1 or caspases sensitizes to necroptosis. ${ }^{13,32}$ Necroptosis, measured as the percentage of $\mathrm{Pl}$-positive nuclei normalized to the platespecific DMSO control, was determined for each compound (Supplementary Figure 1A). Z' values for the TNF- and TNF +TAK1i-induced cell death assay were 0.498 and 0.919 , respectively (Supplementary Figures $2 \mathrm{~A}$ and $\mathrm{B}$ ), indicating good assay performance. Sorafenib was identified as an effective inhibitor of both TNF- and TNF+TAK1i-induced necroptosis (Figure 1a). Sorafenib reduced TNF-induced cell death to $40 \%$ of control, and it almost completely blocked TNF+TAK1i-induced cell death. In an independent screening with 437 FDA-approved drugs and TNF+zVAD-fmk as necroptosis trigger in L929 cells (Supplementary Figure 1B), Sorafenib was also shown to be a potent inhibitor (Figure 1b). Under sensitizing conditions (TAK1i or zVADfmk), Sorafenib $(10 \mu \mathrm{M})$ was equally potent as necrostatin-1 $(10 \mu \mathrm{M})$ and the recently reported RIPK1 inhibitor pazopanib, a multi-target inhibitor of VEGFR1/2/3, PDGFR, FGFR, c-KIT and $\mathrm{C}-\mathrm{Fms} .{ }^{33}$ Other kinase inhibitors from the screening with similar targeting profiles as Sorafenib did not protect against necroptosis (Supplementary Tables 1-3), suggesting that necroptosis inhibition by Sorafenib is not due to inhibition of its known targets (Raf1 kinase, VEGFR1/2/3, PDGFRb, FGFR1 receptor tyrosine kinases). ${ }^{29}$

Sorafenib protects against TNF-induced cell death at non-toxic concentrations. Since Sorafenib induces apoptosis and cytostasis, ${ }^{29,33}$ we determined dose-responses in the presence or absence of necroptosis stimulus. As a chemotherapeutic drug Sorafenib induces cell death in a dose- and time-dependent manner at concentrations above $25 \mu \mathrm{M}$, reaching close to $100 \%$ cell death after $48 \mathrm{~h}$ at $100 \mu \mathrm{M}$ in L929sAhFas cells (EC50 is $39.6 \mu \mathrm{M}$ ) (Figure 1c, left panel; Supplementary Figure 3). A dose-dependent cytostatic effect of Sorafenib was observed 10 days after removal of stimulus in a clonogenic assay (Figure 1d). However, in the same L929sAhFas cells, Sorafenib inhibited necroptosis induced by TNF alone or in sensitized condition (TNF+TAK1i) at concentrations below $10 \mu \mathrm{M}$ without inducing cell death
(Figure 1c, right panel). Altogether, these data demonstrate that Sorafenib is cytotoxic at high concentration on its own, while it protects against TNF-induced necroptosis at more than 10-fold lower concentration (Figure 1c; Supplementary Table 4).

Sorafenib inhibits TNF-induced RIPK1-dependent cell death in murine and human cell lines. To confirm the inhibition of TNF-induced necroptosis by Sorafenib, we tested a panel of murine (L929sAhFas and MEF) and human cell lines (HT-29, Jurkat FADD ${ }^{-/-}$, and two AML cell lines MV4-11 and Molm13). Smac mimetic BV6 ${ }^{34}$ instead of TAK1i was used as a sensitizer for testing of mouse embryonic fibroblasts (MEF) and human cell lines. Dose-response curves and IC50 values for the potency of Sorafenib to inhibit cell death, were determined and compared with Nec-1s, as a reference compound. ${ }^{22}$ As for murine cells, L929sAhFas and MEF cells stimulated with mTNF or with mTNF/smac mimetic BV6/zVAD-fmk (Figures 2a and b), Sorafenib inhibited necroptosis with an IC50 value of $1.27 \mu \mathrm{M}$ and $3.48 \mu \mathrm{M}$ respectively, as compared with $0.24 \mu \mathrm{M}$ and $0.63 \mu \mathrm{M}$ for Nec1s (Figures 2a and b; Supplementary Table 4). To investigate whether the protective effect of Sorafenib at $<10 \mu \mathrm{M}$ is specific for necroptosis, we tested apoptotic conditions in both L929sAhFas and MEF cells. Pretreatment with Sorafenib did not protect L929sAhFas cells from apoptosis induced by agonistic anti-Fas antibody (AF). However, Sorafenib did protect against RIPK1-dependent apoptosis in MEF cells induced by mTNF/BV6 (IC50 of $2.20 \mu \mathrm{M}$ ) (Supplementary Figure $4 \mathrm{~B}$ ). This demonstrates that Sorafenib inhibits RIPK1-dependent apoptosis and necroptosis equally, but not RIPK1-independent apoptosis. As for human cell lines, Sorafenib protected against necroptotic stimuli in HT-29 cells (Figure 2c) as well as Jurkat FADD ${ }^{-/-}$cells (Figure 2d). Since Sorafenib is used to treat $A M L,{ }^{27}$ we also included two AML cell lines to investigate whether it alters the sensitivity of these cells to necroptotic stimuli (BV6 in the presence of zVAD-fmk). ${ }^{34}$ Sorafenib significantly reduced BV6/zVAD-fmkinduced necroptosis of AML cells in a dose-dependent manner (Figures 2e and f). Similar to the L929sAhFas cell line (Figure 1c), the human AML cells underwent Sorafenib-induced cell death (EC50 of 19.6 $\mu \mathrm{M}$ for MV4-11 cells) (Supplementary Figures $4 C$ and $D$ ), while they were protected against BV6+zVAD (IC50 Molm13 of $\leqslant 0.03 \mu \mathrm{M}$ ) (Figures $2 \mathrm{e}$ and $\mathrm{f}$ ). Addition of Nec-1s significantly decreased BV6/zVAD-fmk-mediated necroptosis of AML cells (Figures $2 e$ and $f$ ). In all human cell lines tested Sorafenib protected against necroptosis stimuli (Figures $2 \mathrm{c}-\mathrm{f}$ ) but with variable IC50 values (Supplementary Table 4). Overall, we confirm that Sorafenib at $<10 \mu \mathrm{M}$ protects against TNF-induced RIPK1-dependent cell death, with a three-fold higher efficiency in murine cell lines than in human cell lines.

Sorafenib does not influence the TNF-induced NF- $\kappa$ B activation, but protects against necroptosis by targeting the necrosome complex. We questioned whether NF- $\kappa \mathrm{B}$ mediated survival signaling was involved in the protection by Sorafenib. Similar to Nec-1s, Sorafenib pretreatment did not prevent the phosphorylation and degradation of $I_{\kappa} \mathrm{B}-\alpha$, the inhibitor of NF-kB, ${ }^{35}$ after TNF stimulation of L929 or 


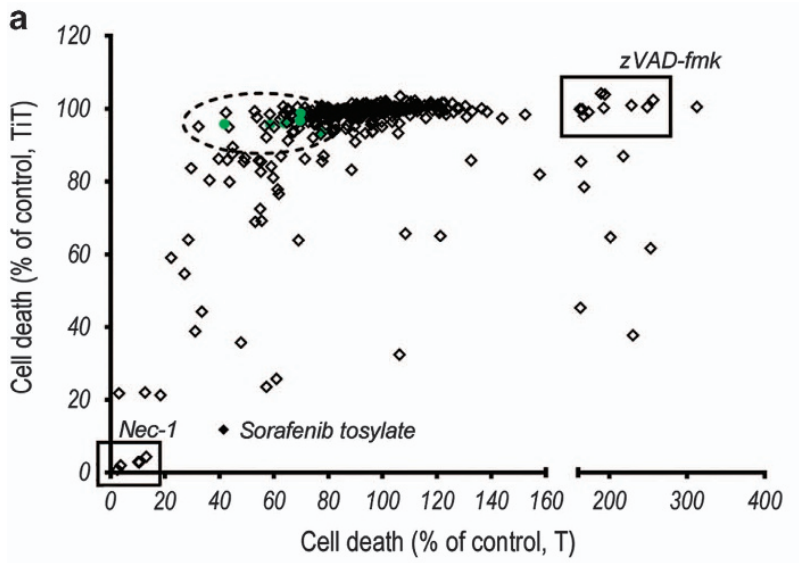

C
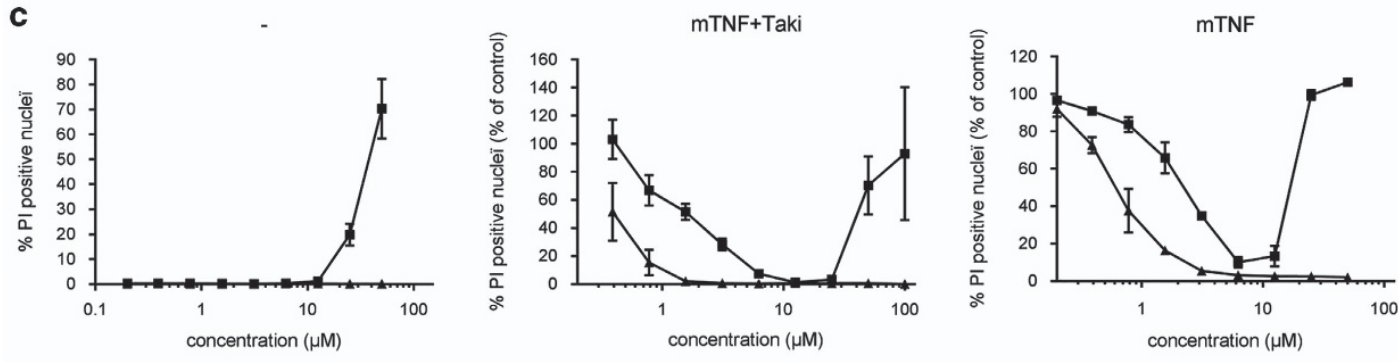

d

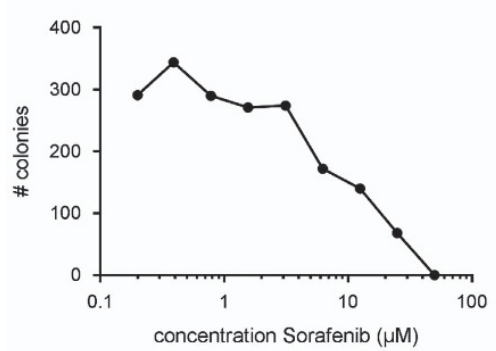

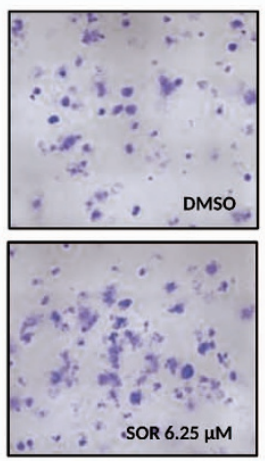

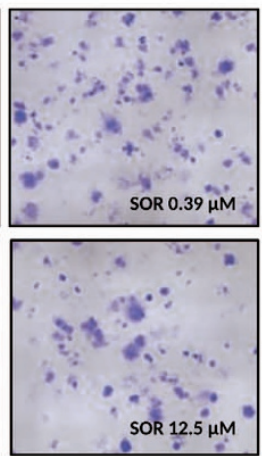

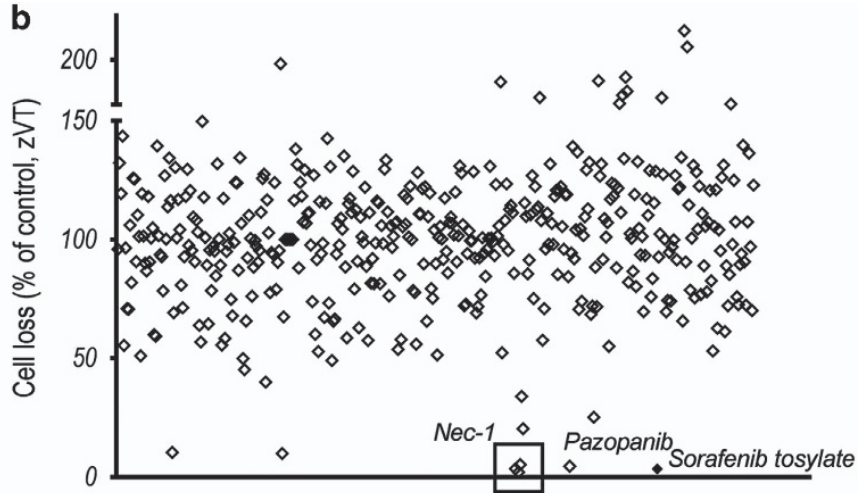

$\rightarrow$ Sorafenib tosylate

+ Nec-1s

Figure 1 Compound screenings in cell models of TNF-mediated necroptosis identify Sorafenib as a potent necroptosis inhibitor, when used at non-cytotoxic concentrations. After compound treatment, L929sAhFas (a) or L929 (b) cells were stimulated with mTNF (T), mTNF+Tak1i (TiT) or mTNF+ZVAD (zVT) (Supplementary Figure 1A and B). (a) Cell death percentage (\% PI-positive nuclei) or cell loss was calculated as percent of control (DMSO+stimulus). Green points marked by the green dotted line represent a selection of kinase inhibitors from the screening on L929sAhFas cells (Supplementary Table 1), that are only slightly protective in the TNF-stimulated condition. (b) Cell loss (luminescencebased readout for ATP) was calculated as percent of control (DMSO+stimulus). (c) L929sAhFas cells were pretreated with DMSO, Nec-1s or Sorafenib (concentrations as indicated) for $19 \mathrm{~h}$ (mTNF+Tak1i) or $1 \mathrm{~h}$ (mTNF), followed by stimulation with $3.8 \mathrm{ng} / \mathrm{ml} \mathrm{mTNF}+1 \mu \mathrm{M}$ Tak1i (mTTi) for $3 \mathrm{~h}, 0.2 \mathrm{ng} / \mathrm{ml} \mathrm{mTNF}$ for $24 \mathrm{~h}$ or left unstimulated to determine cytotoxicity of the compound itself. In stimulated conditions, \% PI-positive nuclei was determined as $\%$ of DMSO control. Data represent mean values \pm S.E.M. of two independent experiments. Cells were stained with Hoechst and PI and percentage PI-positive nuclei was determined using high-content image analysis (BD pathway Bioimager). (d) L929sAhFas cells were treated with Sorafenib (concentration as indicated) for $24 \mathrm{~h}$. Then, stimulus was removed, 50 cells/condition seeded and colonies counted with crystal violet staining after 10 days incubation. Quantification was performed using ImageJ. $n=2$, a representative experiment is shown

L929sAhFas cells (Figure 3a; Supplementary Figure 5). We also examined relative mRNA levels of $\mathrm{NF}-\kappa \mathrm{B}$ responsive genes, including A20 and $\mathrm{I} \mathrm{KB}-\alpha{ }^{36}$ TNF stimulation of L929 cells (Figures $3 b$ and $c$ ) and L929sAhFas cells (Supplementary Figure 6 ) resulted in a ten-fold induction of A20 and I $\kappa$ B- $a$ mRNA, and the presence of Sorafenib did not affect this gene induction. Thus NF- $\kappa \mathrm{B}$ activation after TNF stimulation and subsequent survival signaling is not impaired by Sorafenib. Moreover, Sorafenib did not affect the RIPK1, RIPK3 and MLKL protein levels (Figure 3a), excluding their transcriptional control as a mechanism of Sorafenib-mediated inhibition of necroptosis. Although A20 and $\mathrm{I}_{k} \mathrm{~B}-a$ gene induction was not affected, induction of cytokines and chemokines (TNF- $a$, MIP-2, MCP1 and CXCL1) was strongly reduced by Sorafenib (Supplementary Figure 6), suggesting that other kinases involved in transcriptional regulation are affected by Sorafenib. The above results suggested that the formation of complex I and RIPK1 polyubiquitylation, absolute requirements for NF- $\kappa \mathrm{B}$ signaling, are not impaired by Sorafenib. Indeed, immunoprecipitation of TNFRI after 

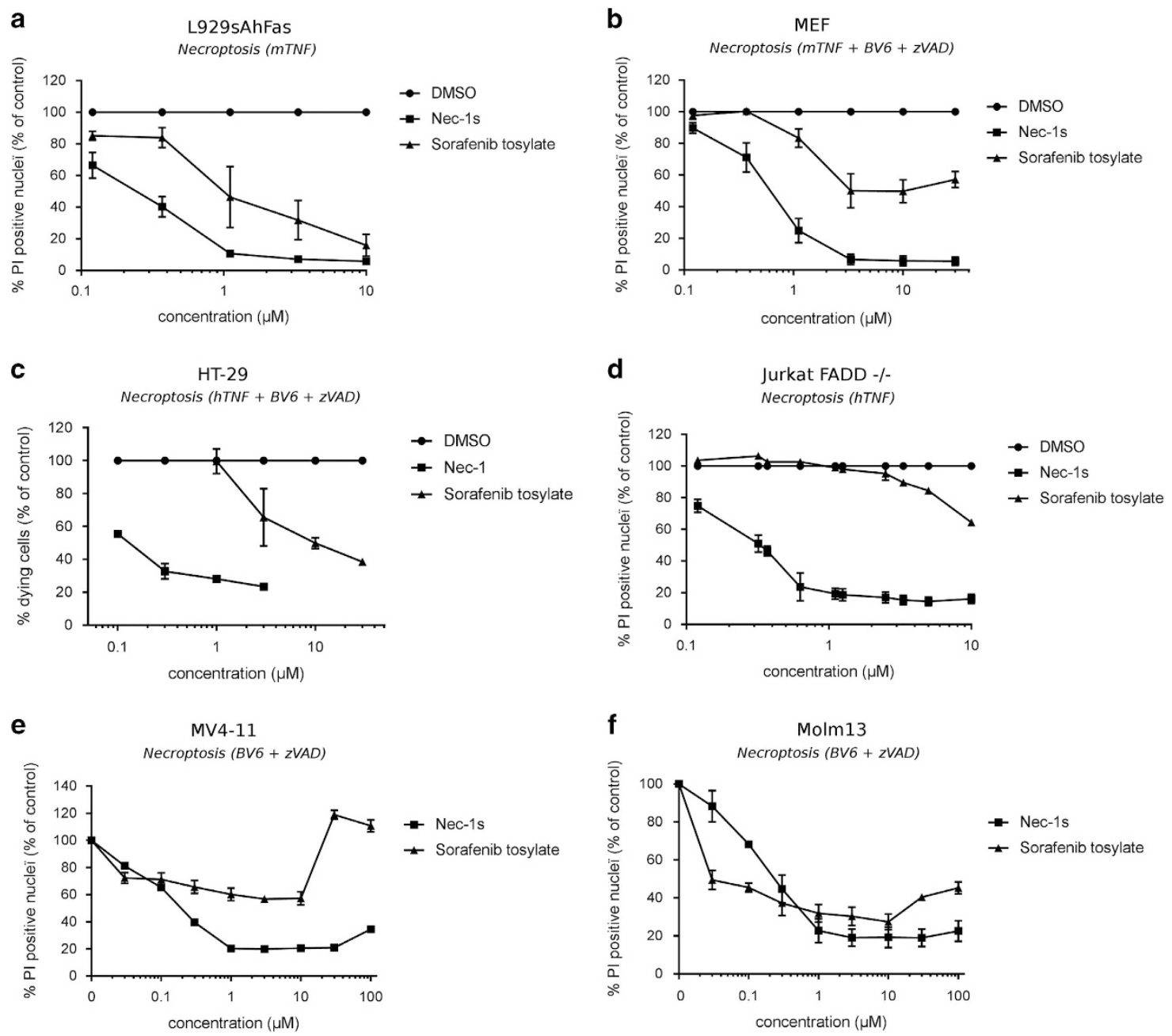

Figure 2 Sorafenib inhibits TNF-induced RIPK1-dependent cell death in both murine and human cell lines and rescues AML cells from Smac mimetic-induced necroptosis. $(a, b)$ L929sAhFas and MEF cells were pretreated for $1 \mathrm{~h}$ with DMSO, Nec-1s or Sorafenib (concentration as indicated) and stimulated for $4.25 \mathrm{~h}$ (L929) or $3 \mathrm{~h}$ (MEF) with $38 \mathrm{ng} /$ $\mathrm{ml}$ mTNF, $1 \mu \mathrm{M} \mathrm{BV6}$ and $10 \mu \mathrm{M}$ zVAD, as indicated. (c,d) HT-29 and Jurkat FADD - / - cells were pretreated for $1 \mathrm{~h}$ with DMSO, Nec-1 or Sorafenib (concentrations as indicated) and stimulated for $6 \mathrm{~h}$ with $30 \mathrm{ng} / \mathrm{ml} \mathrm{hTNF}, 1 \mu \mathrm{M} \mathrm{BV} 6$ and $30 \mu \mathrm{M}$ zVAD (HT-29) or stimulated for $10 \mathrm{~h}$ with $100 \mathrm{ng} / \mathrm{ml}$ hTNF (Jurkat FADD - / - ). (a-d) Data were normalized to DMSO-treated control cells and represent the mean value \pm S.E.M. of three independent experiments. Toxic concentrations were removed from the analysis. L929sAhFas and MEF cells were stained with Hoechst and PI and percentage PI-positive nuclei was determined using high-content image analysis (BD pathway Bioimager). For HT-29 and Jurkat FADD - / - cells, cell death was determined by PI staining and flow cytometry. (e,f) MV4-11 and Molm13 cells were pretreated for $1 \mathrm{~h}$ with $40 \mu \mathrm{M}$ zVAD-fmk and Sorafenib or Nec-1s (concentration as indicated) and stimulated for 6h (Molm13) or 24h (MV4-11) with $3 \mu \mathrm{M} \mathrm{BV6}$. Cell death in AML cells was determined by PI staining and flow cytometry. Mean and S.D. of three independent experiments performed in triplicate are shown

mTNFa stimulation showed similar patterns of RIPK1 polyubiquitylation in both DMSO- and Sorafenib-pretreated L929 cells (Figure $3 \mathrm{~d}$ ). Immunoprecipitation of FLAG-hTNF after $5 \mathrm{~min}$ of stimulation of L929sAhFas cells resulted in polyubiquitylation of RIPK1, which was not altered by $\mathrm{Nec}-1 \mathrm{~s}$ or Sorafenib treatment (Supplementary Figure 7). Next, we investigated whether necrosome formation, involving activation and autophosphorylation of both RIPK1 and RIPK $3,^{5-8}$ was affected by pretreatment with Sorafenib. The recruitment of both RIPK1 and RIPK3 to FADD after 3-4 $\mathrm{h}$ of TNF/zVAD-fmk stimulation of L929 cells was markedly reduced in Sorafenib-treated L929 cells (Figure 3e). Sorafenib not only inhibited necrosome formation in murine L929 cells, but also in human HT-29 cells (Figure 3f). Collectively, these data show that Sorafenib inhibits neither TNF complex I formation nor NF-kB signaling, but interferes with necrosome formation preventing necroptosis to occur.

Identification of RIPK1 and RIPK3 as targets of Sorafenib. Since Sorafenib is a broad-spectrum tyrosine kinase inhibitor, ${ }^{26}$ it may target both RIP kinases and other kinases important for TNF cytotoxic signaling. Prevention of necrosome formation by Sorafenib implies that Sorafenib may interact with RIPK1 and/or RIPK3. To identify targets of Sorafenib during TNF signaling, biotinylated Sorafenib was synthesized (Figure 4a). Several Sorafenib variants were synthesized containing different substituents in the R-position (Supplementary Figure 8), to test whether biotinylation of 


\section{a}

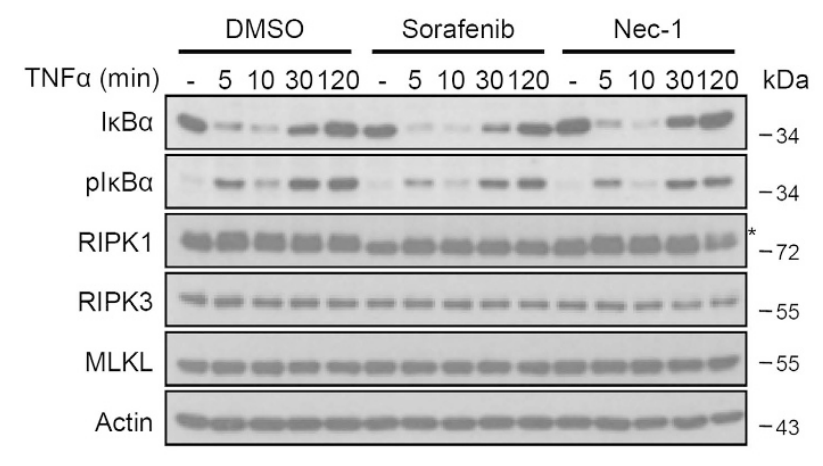

b

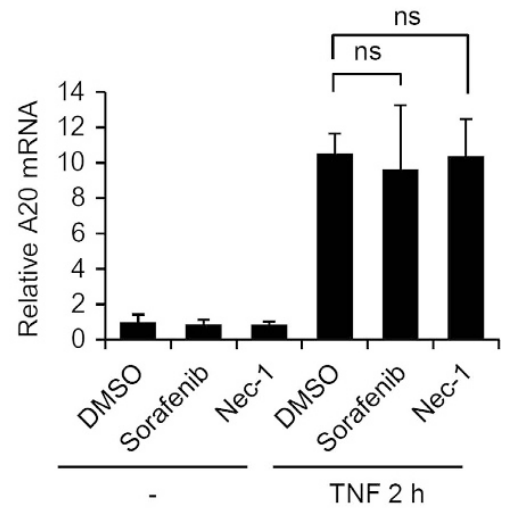

C

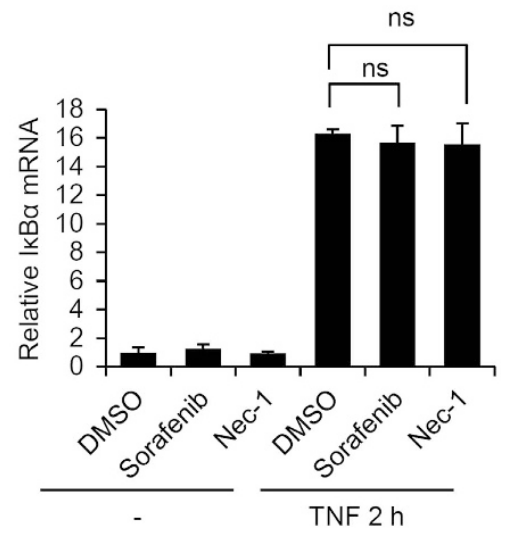

d

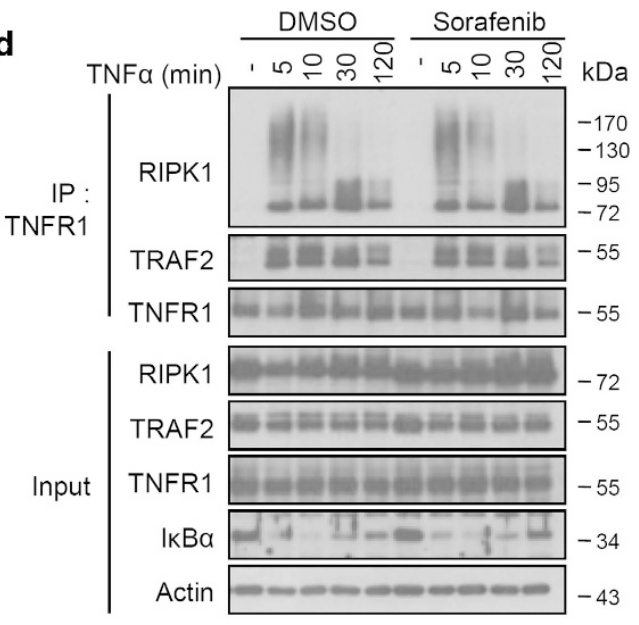

e

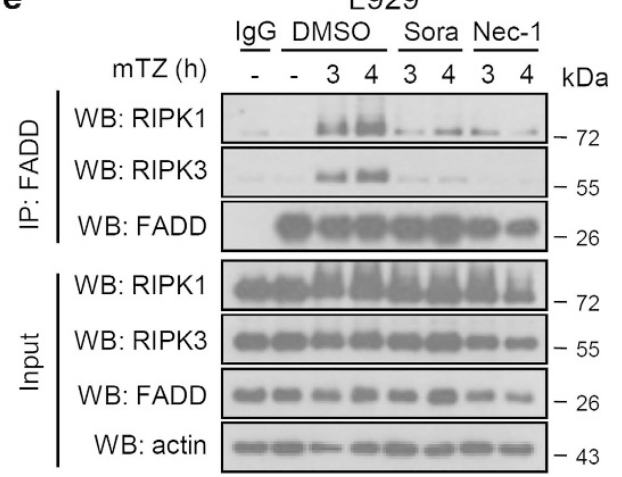

f

HT-29

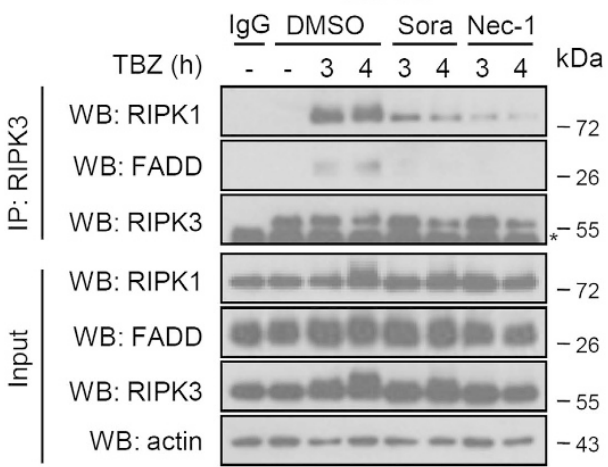

Figure 3 Sorafenib does not influence complex I formation, but protects against necroptosis by targeting the necrosome complex. (a) L929 cells were pretreated with $10 \mu \mathrm{M}$ Nec-1s, Sorafenib or DMSO for $1 \mathrm{~h}$ and stimulated with $\mathrm{mTNF}(10 \mathrm{ng} / \mathrm{ml})$ for the indicated time. Cells were lysed and immunoblotted with the indicated antibodies. ${ }^{*}$ Phosphorylated RIPK1. (b,c) L929 cells were pretreated with $10 \mu \mathrm{M}$ DMSO, Nec-1 or Sorafenib for $1 \mathrm{~h}$ and stimulated with mTNF (10 ng/ml) for $2 \mathrm{~h}$. The relative mRNA levels of $\mathrm{mA} 20$ and $\mathrm{ml} \kappa \mathrm{B}-\alpha$ were analyzed by qRT-PCR. All bars represent mean \pm S.D.; $n=3$, ns = non-significant. (d) L929 cells were pretreated with $10 \mu \mathrm{M}$ Sorafenib or DMSO and stimulated with mTNF (10 ng/ml) for the indicated time. Cell lysates were immunoprecipitated with anti-mTNFR1 antibody. (e,f) L929 (e) and HT-29 (f) cells were pretreated with $10 \mu \mathrm{M} \mathrm{Nec}-1$, Sorafenib (Sora) or DMSO and stimulated with zVAD $(10 \mu \mathrm{M})+\mathrm{mTNF}(5 \mathrm{ng} / \mathrm{ml})(\mathrm{L} 929)$ or ZVAD $(30 \mu \mathrm{M})+\mathrm{BV} 6(1 \mu \mathrm{M})+\mathrm{hTNF}(30 \mathrm{ng} / \mathrm{ml})(\mathrm{HT}-29)$ for the time indicated. Cell lysates were immunoprecipitated with the indicated antibodies and both immunoprecipitates (IP) and total lysates (input) were immunoblotted with the indicated antibodies (WB)

Sorafenib was possible without losing its inhibitory potency. The biotinylated analog of Sorafenib showed a lower inhibitory potency and thus had to be used at higher concentrations for similar efficacy (Supplementary Figure 8, compound 10). To identify binding partners of biotinylated
Sorafenib, a pull down of biotinylated Sorafenib in unstimulated cell lysates of L929sAhFas was performed. We show a dose-dependent pull down of RIPK1, RIPK3, MLKL and B-Raf (Figure 4b; Supplementary Figure 9). Other kinases, like ERK1/2, p38MAPK and HPK1, were not detected in the 
pull down, demonstrating the specificity of the binding. Detection of Hsp90 in the pull down is not suprising, as Hsp90 is known to act as a chaperone for RIPK1 stabiliza- tion, ${ }^{37}$ RIPK3 activation ${ }^{38}$ and MLKL oligomerization ${ }^{39}$ during necroptosis execution (Figure 4b). These data suggested that Sorafenib binds either to a (pre-formed) multi-protein complex b

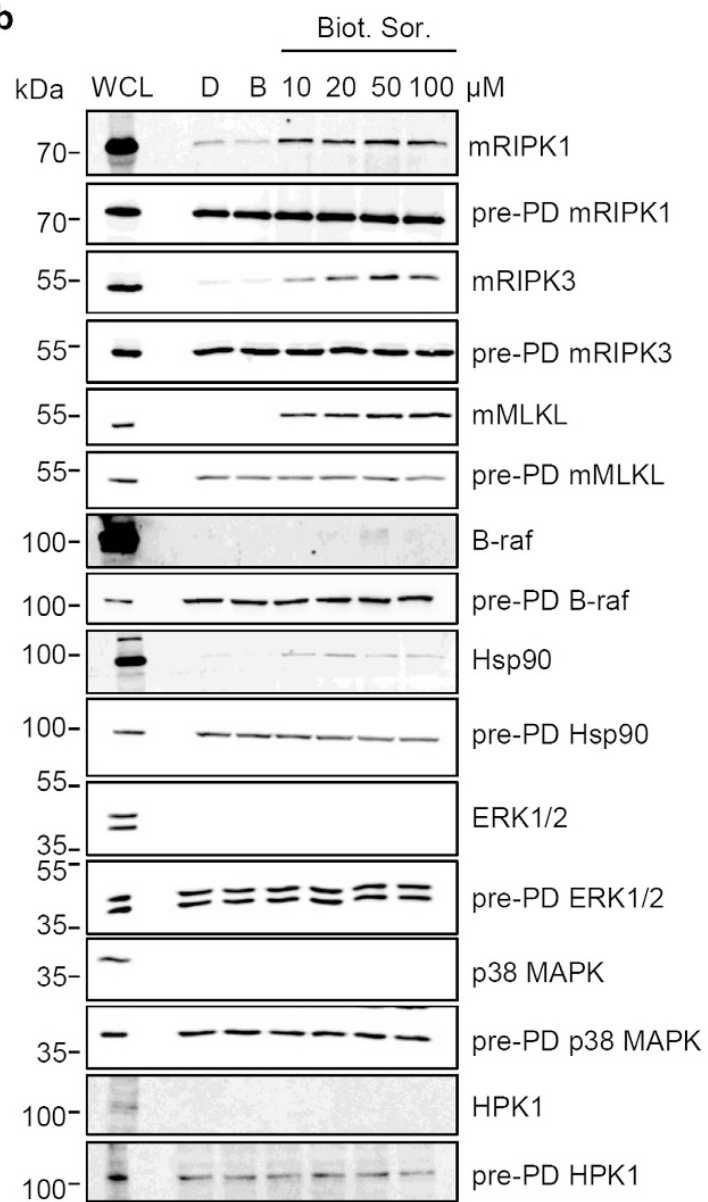

a<smiles>O=C(CCCCC12CNC1NC(=O)N2)NCCOCCOCCNC(=O)c1cc(Oc2ccc(NC(=O)NCCOCC3NC4CC34)cc2)ccn1</smiles>

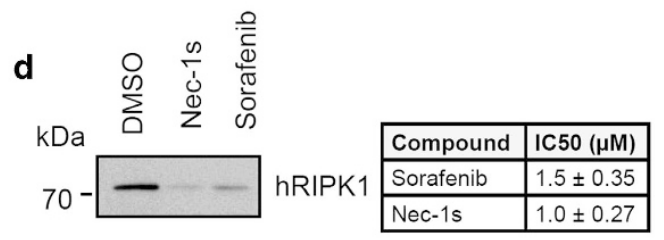

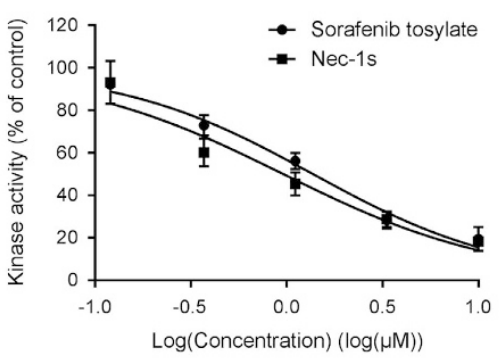

e

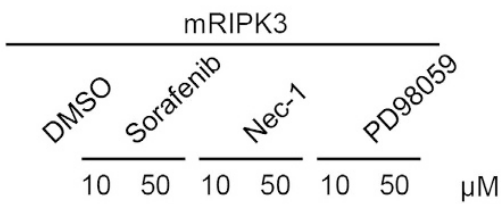

$\mathrm{kDa}$

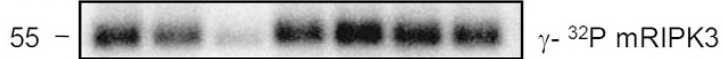

C

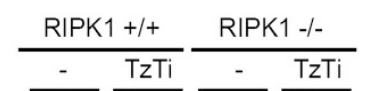

$\frac{\mathrm{RIPK}^{+}+/+}{-} \frac{\mathrm{RIPK} 3-/-}{-}$

$\mathrm{kDa} \overline{\mathrm{DBS}} \overline{\mathrm{DBS}} \overline{\mathrm{DBS}} \overline{\mathrm{DBS}}$ $\overline{D B S} \overline{D B S} \overline{D B S} \frac{T Z T S}{D B S}$
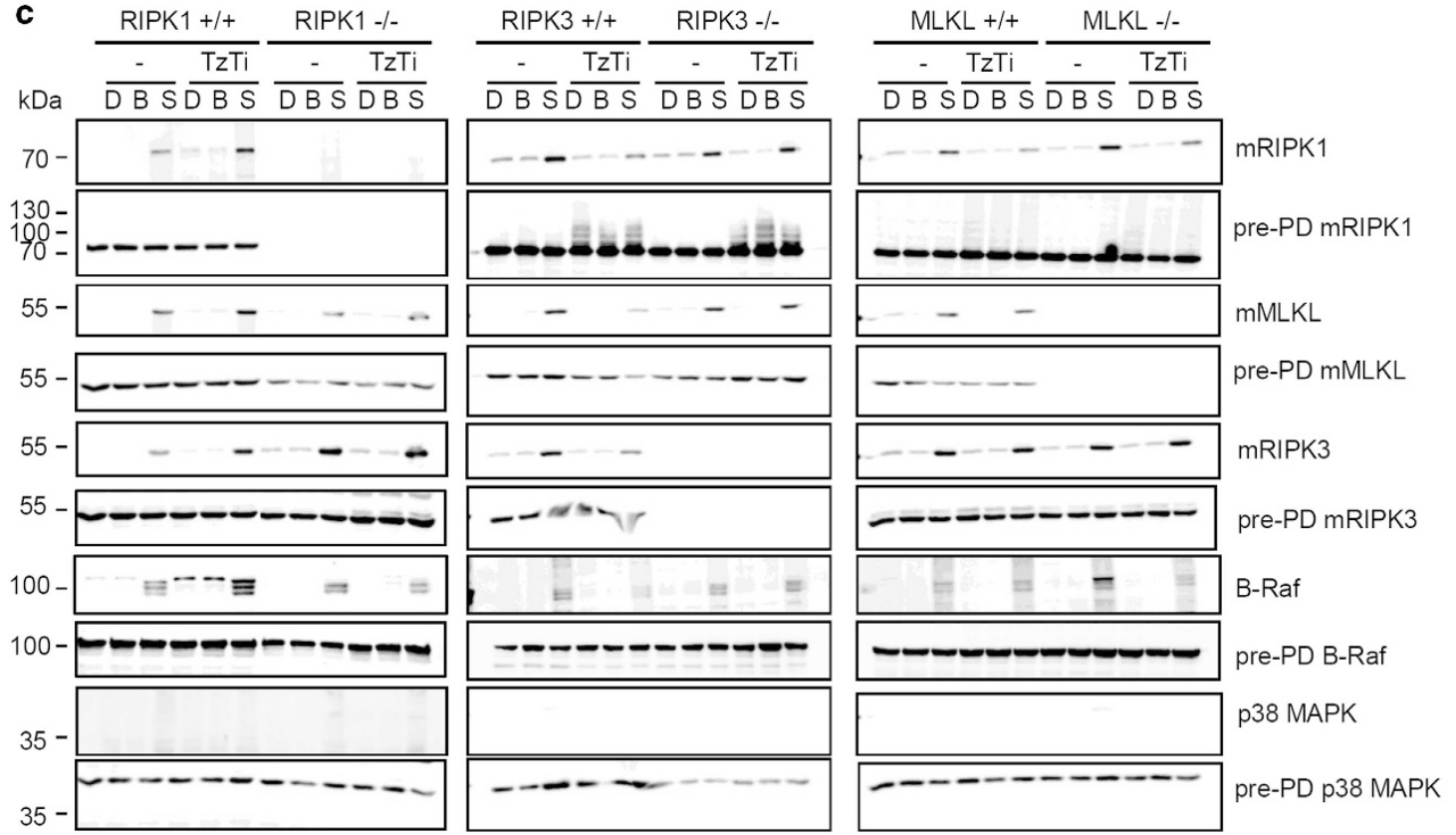
containing RIPK1, RIPK3 and MLKL or to all three proteins independently. Interestingly, we were able to pull down each of the three necrosome components (RIPK1, RIPK3, MLKL) in MEF cell lysates from the following mice strains: RIPK1+/+, RIPK1 -/ - , RIPK3+/+, RIPK3 -/ - , MLKL+/+ and MLKL -/ - . This experiment demonstrates that Sorafenib is likely to bind independently to RIPK1, RIPK3 or MLKL (Figure 4c), even in the absence of a necroptotic stimulus. Together with the data of the immunoprecipitation of TNFR1 (complex I) and FADD (complex II) after TNF stimulation, we conclude that Sorafenib can bind RIPK1, RIPK3 and MLKL and hereby prevents the formation of the necrosome.

In order to test whether Sorafenib directly inhibits kinase activities of RIPK1 or RIPK3, different in vitro kinase assays were performed (Figures $4 d$ and $e$ ). A non-radioactive in vitro ATPyS kinase assay was performed with recombinant GSThRIPK1. ${ }^{40}$ Incubation of recombinant GST-hRIPK1 with Nec1s or Sorafenib resulted in a strong decrease in RIPK1 autophosphorylation compared with the DMSO control, although Sorafenib was less efficient than $\mathrm{Nec}-1 \mathrm{~s}$ (Figure 4d, upper figure). IC50 values of Sorafenib and Nec1s were $1.5 \mu \mathrm{M}$ and $1 \mu \mathrm{M}$ respectively in an in vitro ADP-Glo kinase assay ${ }^{41}$ using recombinant hRIPK1 (Figure 4d, lower figure), confirming the results of the in vitro ATPyS kinase assay. Finally, $50 \mu \mathrm{M}$ Sorafenib inhibited mRIPK3 autophosphorylation in a radioactive kinase assay with FLAG-mRIPK3 (Figure 4e). Although Sorafenib can bind to MLKL in cell lysate, it does not protect against ligand independent MLKLinduced cell death (Supplementary Figure 10), excluding functional targeting on MLKL. Altogether, these data illustrate that Sorafenib can bind to RIPK1 and RIPK3 and inhibit their kinase activities.

Sorafenib protects against TNF-induced systemic inflammatory response syndrome and renal ischemia-reperfusion injury. To examine whether Sorafenib could protect against RIPK kinase-driven inflammation in vivo, we tested it in the TNF-induced SIRS model. This is a sterile model of sepsis that depends on RIPK1 kinase activity and RIPK3. ${ }^{42,43}$ Sorafenib, administered by gavage $1.5 \mathrm{~h}$ before i.v. mTNF treatment, significantly protected mice from hypothermia and death caused by mTNF in a dose-dependent manner (Figures $5 \mathrm{a}$ and b). Mice pretreated with $\mathrm{Nec}-1 \mathrm{~s}$ were fully protected, while about $50 \%$ of mice pretreated with Sorafenib survived (Figure 5a). The IL-6 concentration in plasma of Sorafenib-treated mice $(100 \mathrm{mg} / \mathrm{kg})$, like Nec-1s-treated mice, are significantly lower than vehicle-treated mice after $6 \mathrm{~h}$ TNF challenge (Figure $5 \mathrm{~d}$ ). On the other hand, TNF concentration was not significantly lower under these conditions (Figure 5e). In conclusion, these results indicate that Sorafenib not only protects against RIPK1/3-dependent cell death in vitro, but also against RIPK1/3-dependent lethality in TNF-induced SIRS. As Nec-1 treatment and RIPK3-deficiency are beneficial in the model of renal ischemia-reperfusion injury, ${ }^{44,45}$ we investigated the effect of Sorafenib in this model of tissue injury and inflammation as well. Low-dose Sorafenib protected against histological damage (Figures $5 f$ and $g$ ) and functionally ameliorated acute renal failure, as demonstrated by reduced serum creatinine and urea $48 \mathrm{~h}$ after reperfusion (Figures $5 \mathrm{~h}$ and i). Higher dose of Sorafenib however sensitized the mice to ischemic damage and led to deterioration of acute renal failure (Supplementary Figure 11). We conclude that Sorafenib provided protection in two in vivo models of tissue injury and inflammation driven by RIPK1/RIPK3-dependent cell death.

\section{Discussion}

We performed cellular screenings with targeted small compound libraries (for kinases, phosphatases, proteases, redoxregulation, autophagy) and an FDA-approved drug library in order to identify inhibitors of necroptosis. From the results, we selected Sorafenib for further characterization as an inhibitor of necroptosis, not only because it protected against different necroptosis inducing stimuli but also because it is an FDAapproved drug that is used in clinic to treat advanced hepatocellular carcinoma, ${ }^{46}$ renal cell carcinoma ${ }^{47}$ and AML. ${ }^{27}$ Several necroptosis inhibitors have been discovered or designed to target RIPK1, ${ }^{5,48}$ RIPK3 $^{49}$ and MLKL, ${ }^{50,51}$ the core necroptosis pathway, ${ }^{52}$ but none of them are already in clinical use. ${ }^{53}$ Sorafenib is not the only anti-cancer drug that can inhibit necroptosis. Recently, Pazopanib, first proposed as a multi-target inhibitor of VEGFR1/2/3, PDGFR, FGFR, c-KIT and $\mathrm{C}-\mathrm{Fms}$ and approved for the treatment of advanced renal cell carcinoma, and Ponatinib, first described as Pan-Bcr-Abl tyrosine kinase inhibitor and approved for the treatment of chronic myeloid leukemia, were both reported as necroptosis inhibitors at the submicromolar range, ${ }^{33}$ the former blocking mainly RIPK1 and the second blocking both RIPK1 and RIPK3. Ponatinib has been used as template to design new inhibitors with improved selectivity for RIPK1. ${ }^{54}$ The B-Raf ${ }^{\mathrm{V} 600 \mathrm{E}}$ inhibitors Vemurafenib and Dabrafenib inhibit RIPK3, with Dabrafenib being effective in the submicromolar range. ${ }^{55}$ Dabrafenib competes with ATP for binding to RIPK3 and alleviates acetaminophen-induced liver injury. ${ }^{55}$ Here, we demonstrate that the anti-cancer agent Sorafenib acts as an inducer of cell death at high concentration but as an inhibitor of RIPK-dependent cell death at lower concentration.

\footnotetext{
Figure 4 Identification of RIPK1 and RIPK3 as targets of Sorafenib tosylate. (a) Structure of biotinylated Sorafenib tosylate. (b,c) Streptavidin pull down of biotinylated Sorafenib. DMSO (D), biotin (b) or $10 \mu \mathrm{M} / 20 \mu \mathrm{M} / 50 \mu \mathrm{M} / 100 \mu \mathrm{M}$ biotinylated Sorafenib (biot. Sor.) was added to L929sAhFas cell lysate and $50 \mu \mathrm{M}$ biotinylated Sorafenib (S) to MEF cell lysates, followed by pull down with streptavidin beads. Both pull down samples and total lysates (pre-PD) were analyzed by SDS-PAGE and immunoblotted with the indicated antibodies. L929sAhFas whole cell lysate (WCL) was included as loading control. (d) In vitro non-radioactive ATP $\gamma$ S kinase assay (upper figure) and in vitro ADP-Glo kinase assay (lower figure and table) using recombinant hRIPK1 protein (100 nM). Recombinant hRIPK1 was incubated with $50 \mu \mathrm{M}$ Nec-1s, Sorafenib or DMSO (upper figure) or with a concentration as indicated. (e) FLAG-mRIPK3 purified from 293FT cells was pre-incubated with indicated chemicals (conc. as indicated) for 15 min at $25^{\circ} \mathrm{C}$ and incubated with $\left[\gamma^{-32} \mathrm{P}\right] A T P$ for in vitro radioactive kinase assay
} 
The kinase domain of B-raf ${ }^{\mathrm{V} 600 \mathrm{E}}$ has strong structural homology with the kinase domains of hRIPK1 and hRIPK3, which explains the similarities between the crystal structure of
Nec-1 bound to RIPK1 and the structure of Vemurafenib bound to B-Raf ${ }^{\mathrm{V} 600 \mathrm{E}}{ }^{56}$ The crystal structure of B-Raf bound to Sorafenib indicates that Sorafenib occupies the ATP-binding a

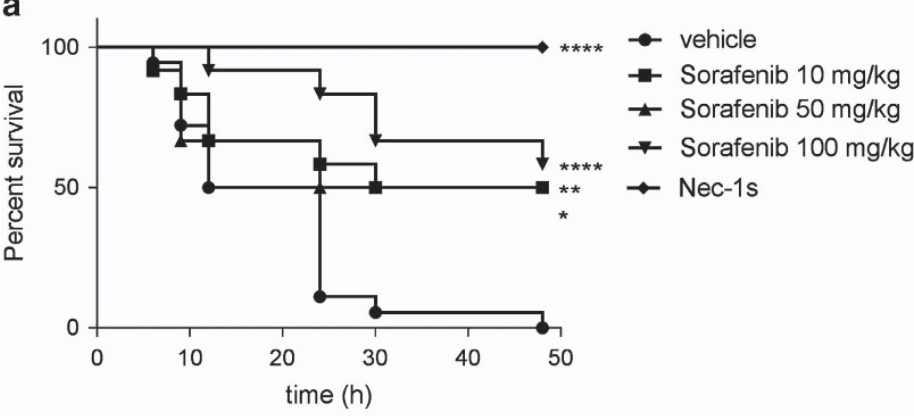

C

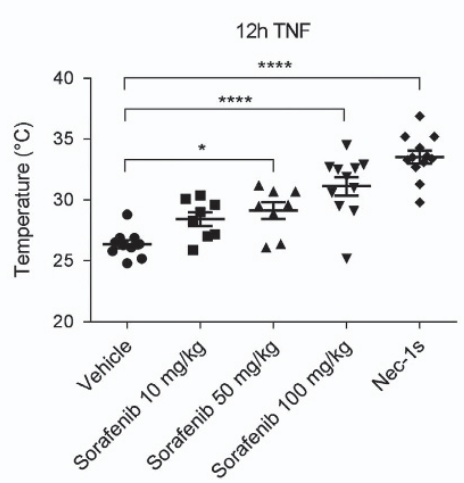

d

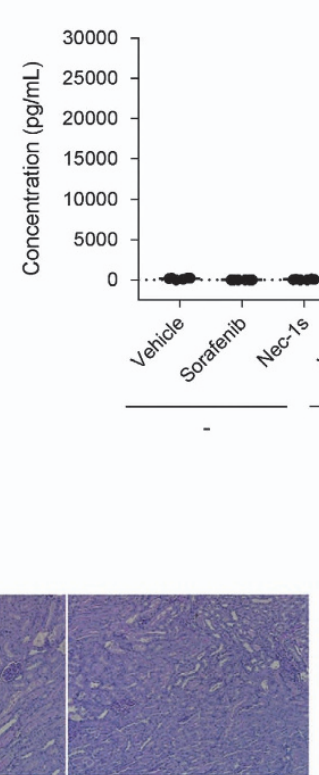

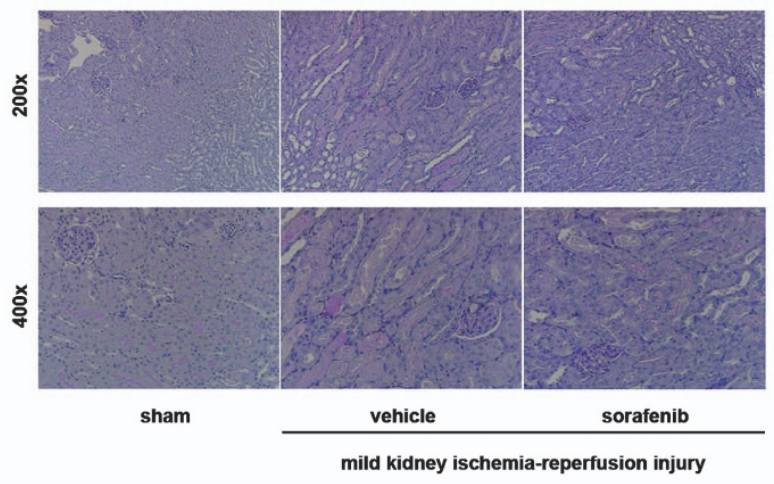

f
IL-6

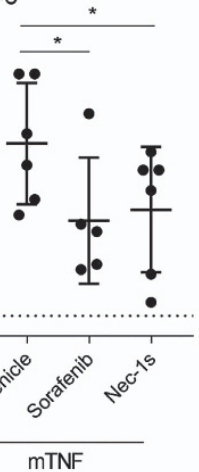

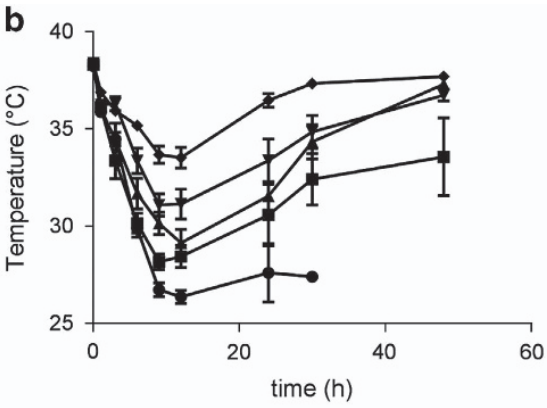

e

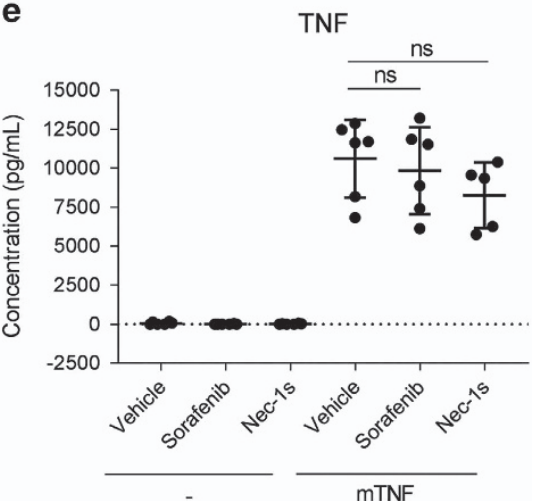

g

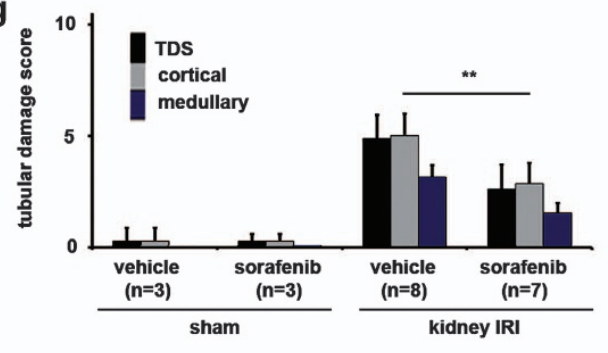

h

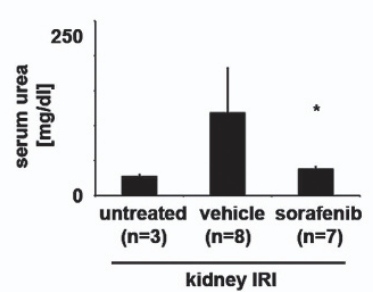

i

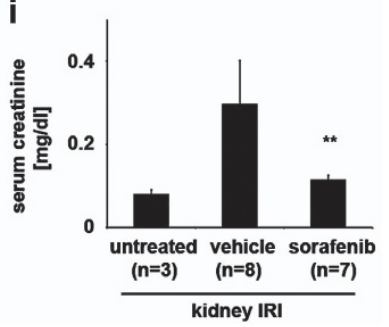

Figure 5 Sorafenib protects against TNF-induced systemic inflammatory response syndrome (SIRS) and renal ischemia-reperfusion injury (IRI). Survival curve (a) and body temperature $(\mathbf{b}, \mathbf{c})$ (means \pm S.E.M.) of WT mice $(n=12)$ injected with mTNF $(500 \mu \mathrm{g} / \mathrm{kg}$ i.v.) after pretreatment with Nec-1s $(6.25 \mathrm{mg} / \mathrm{kg}$ i.v.) or Sorafenib $(10 / 50 / 100 \mathrm{mg} / \mathrm{kg}$ gavage). Control mice $(n=12)$ received an equal amount of vehicle before the mTNF challenge. Results of three independent experiments are shown. (d,e) Plasma samples of Solvent-, Nec-1s- (6.25 mg/kg i.v.) and Sorafenib-treated mice (100 mg/kg gavage) $(n=6 /$ group) were collected $0 \mathrm{~h}$ and $6 \mathrm{~h}$ after mTNF challenge ( $375 \mu \mathrm{g} / \mathrm{kg}$ i.v.) and analyzed for mTNF- $\alpha$ and mIL-6. (c-e) A one-way ANOVA test with Bonferroni multiple-testing correction was performed. ${ }^{*} P<0.05,{ }^{* *} P<0.01$, and ${ }^{\star * \star *} P<0.0001$ versus control mice. (f-i) Histology, tubular damage score and serum urea/creatinine levels of mice treated with vehicle or Sorafenib (10 mg/kg i.p.) 15 min before initiation of ischemia. Mice were killed $48 \mathrm{~h}$ after reperfusion and kidneys were removed after retro-orbital blood puncture. Stained kidney sections were analyzed using an Axio Imager microscope (Zeiss). Organ damage was quantified by an experienced pathologist in a double-blind manner on a scale ranging from 0 (unaffected tissue) to 10 (severe organ damage), ${ }^{\star} P<0.05$ and ${ }^{* *} P<0.01$ 
pocket and keeps the protein in an inactive conformation. ${ }^{57}$ As the broad-spectrum tyrosine kinase inhibitor Sorafenib was originally designed as a Raf1-inhibitor, ${ }^{26}$ and given the homology between B-Raf ${ }^{\mathrm{V} 600 \mathrm{E}}$ and the kinase domain of hRIPK $1 / 3,{ }^{56}$ we speculated that Sorafenib could also bind RIPK $1 / 3$ by targeting the kinase domain. The protection of Sorafenib against TNF-induced necroptosis cannot be explained by inhibition of its known targets (Raf B/C kinase, VEGFR1/2/3, PDGFR, c-KIT, RET, FIt3), ${ }^{58}$ since small compounds with similar target profiles, like Vandetanib targeting VEGFR-2/KIT/PDGFR, do not protect from necroptotic cell death. ${ }^{33}$ Also, compounds like GW5074, SU1498, Tyrphostin AG1295 and PP1, targeting Raf kinase, VEGFR, PDGFR and Src kinase respectively do not inhibit necroptosis (Supplementary Tables 1-3). Moreover, we show that Sorafenib can bind either a complex containing RIPK1, RIPK3 and MLKL or to each of these proteins separately. Finally, we showed that Sorafenib protected against two models of RIPKdriven inflammation and tissue injury, namely TNF-induced SIRS, a sterile model for sepsis, ${ }^{42}$ and renal ischemiareperfusion injury (IRI) ${ }^{59}$ It has been shown that Sorafenib can be used efficiently to block Hepatitis $C$ virus replication and viral gene expression ${ }^{60}$ and Rift Valley fever virus infection. ${ }^{61}$ It is also reported that Sorafenib can protect against ischemia/ reperfusion (IR) injury in rats with nonalcoholic steatohepatitis, ${ }^{62}$ is able to reverse LPS-induced hypotension by targeting soluble epoxide hydrolase (sEH), an enzyme with pleiotropic effects on inflammation and vascular disease, ${ }^{63}$ and is also able to restore working memory abilities in a mouse model for Alzheimer's disease (AD) by inhibition of the proneuroinflammatory factor $c$ Raf- 1 and NF- $k B$. ${ }^{64}$ Thus Sorafenib exerts an anti-inflammatory activity in other in vivo experimental diseases models. Given the inflammatory response triggered by release of cytokines, chemokines and DAMPs from necroptotic dying cells, ${ }^{42,59}$ these reported antiinflammatory effects of Sorafenib in vivo may be attributed to its potent necroptosis targeting effect we describe here. In $\mathrm{HCC}$, chronic inflammation is known to promote tumor progression and metastasis, with a pivotal role for TNF in promoting invasion, angiogenesis and metastasis. ${ }^{65,66}$ As necroptosis through DR6 in tumor-associated endothelial cells has been described as a metastasis promoting process, ${ }^{67}$ the efficacy of Sorafenib in HCC could, besides the direct cytotoxicity on tumor cells, be due to necroptosis inhibition preventing pro-inflammatory DAMP release in the necrotic core and so reducing the inflammation-dependent tumor growth $^{68}$ and preventing endothelial necroptosis and metastasis. ${ }^{67}$ As Sorafenib is not specifically inhibiting necroptosis but also RIPK1 kinase dependent apoptosis, one could envisage that during experimental disease models in vivo it may target simultaneously RIPK1-dependent necroptosis and apoptosis. Recent evidence illustrates that TNF-induced SIRS is a consequence of both caspase-8dependent apoptosis and MLKL-dependent necroptosis. ${ }^{43}$ Sorafenib inhibits both RIPK1-dependent apoptosis and necroptosis, which may explain its protective effect during TNF-induced SIRS model.

Repurposing FDA-approved drugs is a new and valuable strategy to offer new therapies for diseases that remain difficult to treat ${ }^{69,70}$ such as sepsis, degenerative disorders and metabolic diseases. However, more extensive in vivo experiments need to be performed to explore possible repurposing of Sorafenib to treat these human disease conditions. Our data also indicate that Sorafenib at low concentrations can interfere with therapeutic induction of necroptotic cell death in AML cells. Since some targeted therapies such as Smac mimetic in combination with epigenetic drugs have been shown to trigger necroptosis as an alternative mode of cell death in apoptosisresistant $A M L$ cells, ${ }^{71,72}$ these findings imply that Sorafenib may limit the anti-leukemic activity under certain conditions. To conclude, we identified the necroptotic pathway as a novel Sorafenib-targeted pathway through inhibition of the necrosome formation. We also demonstrated that Sorafenib alleviated inflammation and tissue injury in two experimental disease models in mice which are driven by RIPK-dependent cell death, suggesting that necroptosis targeting could be part of the therapeutic potential of Sorafenib.

\section{Materials and Methods}

Cell culture, cytokines and reagents. L929 cells were purchased from ATCC (used in Korean Lab), L929 cells stably transfected with hFas and designated as L929sAhFas (used in Belgian Lab) were generated as previously described. ${ }^{14}$ All L929 cell lines and MEF cells were cultured in DMEM supplemented with $10 \%$ (v/v) FCS and L-glutamine (0.03\%). Jurkat FADD ${ }^{-1-}$ cells were cultured in RPMI medium supplemented with $15 \%$ (v/v) FCS, sodium pyruvate $(400 \mu \mathrm{M})$ and L-glutamine $(0.03 \%)$. HT-29 cells were cultured in McCoy's $5 \mathrm{~A}$ medium supplemented with $10 \%(\mathrm{v} / \mathrm{v})$ FBS. AML cell lines were obtained from DSMZ (Braunschweig, Germany) and were cultured in RPMI 1640 medium (Life Technologies, Eggenstein, Germany), supplemented with 10\% FCS (Biochrom, Berlin, Germany), $1 \mathrm{mM}$ Pyruvate (Invitrogen, Karlsruhe, Germany) and 1\% penicillin/streptomycin (Invitrogen). Following cytokines and reagents were used: recombinant (rec) human and murine TNF were produced at VIB protein Service Facility (Ghent, Belgium) with a specific biological activity of $3 \times 10^{7} \mathrm{IU} / \mathrm{ml}$ and $1.27 \times 10^{8} \mathrm{IU} / \mathrm{ml}$ (batch 2: $4.93 \times 10^{7} \mathrm{IU} / \mathrm{ml}$ ) respectively, human and murine rec TNF were also purchased from Sigma-Aldrich (T0157) and eBioscience (14-8321-62) respectively (Korean Lab), rec FLAG-hTNF was produced at VIB Protein Service Facility (Ghent, Belgium) and was used at $1.5 \mu \mathrm{g} / \mathrm{ml}$. Following reagents were purchased as indicated: necrostatin-1 (Calbiochem, San Diego, CA, USA and Enzo life science, Farmingdale, NY, USA), necrostatin-1s (synthesized by the laboratory of Medicinal Chemistry; University of Antwerp), Sorafenib tosylate (Selleck Chemicals, Houston, TX, USA), SMAC mimetic BV6 (Selleck Chemicals), Tak1 kinase inhibitor NP-009245 (AnalytiCon Discovery GmbH, Potsdam, Germany), zVAD-fmk (Bachem, Bubendorf, Switzerland and R\&D systems) and agonistic antihuman Fas (clone 2R2, Cell Diagnostica, Munster, Germany). Libraries used are: autophagy library (BML-2837), epigenetics library (BML-2836), kinase inhibitor library (BML-2832), phosphatase inhibitor library (BML-2834), protease inhibitor library (BML-2833), redox library (BML-2835) (Screen-well, Enzo Life Sciences) and 437 FDA-approved drug library (SelleckChem, L1300).

Antibodies. Antibodies used were anti-RIPK1 (BD Biosciences, San Jose, CA, USA, \#610459), anti-actin (MP Biomedicals, Solon, OH, USA, \#69100), anti-IkB- $\alpha$ (Santa Cruz Biotechnology, Dallas, TX, USA, \#Sc-371), anti-hRIPK3 (ThermoFisher Scientific Pierce, Waltham, MA, USA, PA1-41533), anti-mRIPK3 (Sigma-Aldrich, St Louis, MO, USA, \#R4277 and IMGENEX, San Diego, CA, USA,, IMG-5523-2), antihMLKL (Genetex, Irvine, CA, USA, GTX107538), anti-mMLKL (Millipore, Billerica, MA, USA, \#MABC604 and Abgent, San Diego, CA, USA, AP14272b-ev), antiphospho-hMLKL (Abcam, Milton, Cambridge, UK, \#187091), anti-hFADD (BD Biosciences, 610399), anti-mFADD (Millipore, 05-486), anti-thiophosphate ester (Epitomics, Burlingame, CA, USA, \#2686-1), anti-Braf (ThermoFisher scientific, MA5-15495), anti-HPK1 (Cell Signaling, Danvers, MA, USA, \#4472), anti-Hsp90 (Santa Cruz Biotechnology, sc-7947), anti-p38MAPK (Cell Signaling, \#9212), antiERK1/2 (Cell Signaling, \#9102), anti-Flag-HRP (Sigma-Aldrich, St Louis, MO, USA, \#A8592) and anti-tubulin-HRP (Abcam, \#ab21058). Secondary antibodies used were HRP-conjugated secondary antibodies against mouse, rabbit or rat immunoglobulin (GE Healthcare, Little Chalfont, Amersham, UK). 
Immunoprecipitation. For TNFRI complex I and necrosome IP, DISC buffer composed of $50 \mathrm{mM}$ Tris- $\mathrm{HCl}(\mathrm{pH} 7.5), 150 \mathrm{mM} \mathrm{NaCl}, 1 \mathrm{mM}$ EDTA, $1 \%$ Triton $\mathrm{X}-100$, protease inhibitors and $10 \%$ glycerol were used to lyse pretreated L929 or HT-29 cells. After the lysis step, each complex was purified by IP using $1 \mu \mathrm{g}$ of $\alpha$-mTNFR1 (R\&D systems, AF-425-PB) for TNFRI complex I, $1 \mu \mathrm{g}$ of $\alpha$-mFADD (Santa cruz, sc-6036) for mouse necrosome or $1 \mu \mathrm{g}$ of $\alpha$-hRIPK3 (ThermoFisher Scientific Pierce, PA1-41533) at $4{ }^{\circ} \mathrm{C}$. In order to pull down each antibody-bound complex, protein $G$ agarose beads (GE Healthcare, 17-0618-01) were incubated with cell lysates for $2 \mathrm{~h}$, followed by $3 \mathrm{x}$ washing with DISC buffer. The immunoprecipitated complexes were eluted in boiled condition and analyzed by immunoblotting (antibodies used as indicated). Pull down of biotinylated Sorafenib was performed by adding DMSO, biotin or biotinylated Sorafenib (10/20/50/100 $\mu \mathrm{M})$ to L929sAhFas cell lysates or MEF cell lysates and incubating with Streptavidin Sepharose High Performance (GE Healthcare, 17-5113-01). Beads were blocked with $0.5 \% \mathrm{BSA}$ (150 mM NaCl, $10 \mathrm{mM}$ Tris- $\mathrm{HCl} \mathrm{pH} \mathrm{8,} \mathrm{10 \%} \mathrm{glycerol,} \mathrm{0.5 \%} \mathrm{BSA)}$ before use. After incubation with cell lysates, streptavidin beads were washed with ice-cold NP-40 lysis buffer ( $150 \mathrm{mM} \mathrm{NaCl}, 10 \mathrm{mM}$ Tris- $\mathrm{HCl}$ pH 8, 10\% glycerol, $1 \%$ NP-40) and eluted by directly adding $2 x$ Laemli buffer. Samples were boiled and analyzed by immunoblotting (antibodies used as indicated).

Cell death analysis. Cell death was analyzed using a BD Pathway 855 highcontent screening instrument (BD Biosciences) (first screening, Figure 1a). ${ }^{73}$ Ten thousand cells were seeded in a black-clear 96-well plate. The next day, the cells were pretreated with the indicated compounds for $1 \mathrm{~h}$ and then stimulated with mTNF, hTNF or agonistic anti-Fas Ab (concentration as indicated) in the presence of $3 \mu \mathrm{M}$ propidium iodide (Sigma-Aldrich) and $1 \mu \mathrm{M}$ Hoechst (Sigma-Aldrich). Images of at least 1000 cells were taken using a 10x objective and acquired data were analyzed using the Columbus software package. The percentage PI-positive nuclei was determined as a measure for cell death. For the second screening shown in Figure $1 b$, cell death was measured by incubating dying cells with Cell Titer Glo reagent (Promega, G7571) for $20 \mathrm{~min}$, followed by analysis using a luminometer according to the manufacturer's protocol. All data on L929sAhFas and MEF cells were analyzed using the BD Pathway imager.

Systemic inflammatory response syndrome. All in vivo experiments were conducted according to institutional, national and European regulations. Animal protocols were approved by the ethics committee of Ghent University (SIRS model). Female C57BL/6 J mice (7-8 weeks old) were purchased from Janvier (Le Genest, France) for all SIRS experiments. To study the effect of Sorafenib on TNF-induced SIRS in mice, mice were challenged with $10 \mu \mathrm{g} \mathrm{mTNF}(500 \mathrm{mg} / \mathrm{kg})$ in the presence or absence of Sorafenib. Nec-1s served as a positive control, since it was shown to protect against TNF-induced SIRS. ${ }^{42,74} \mathrm{Nec}-1 \mathrm{~s}(125 \mu \mathrm{g} ; 6.25 \mathrm{mg} / \mathrm{kg})$ was injected intravenously (i.v.) $15 \mathrm{~min}$ before $\mathrm{mTNF}-\alpha$ challenge, whereas Sorafenib $(10,50$ or $100 \mathrm{mg} / \mathrm{kg})$ or vehicle was given by gavage $1,5 \mathrm{~h}$ before mTNF- $\alpha$ challenge. mTNF- $\alpha(10 \mu \mathrm{g})$ was injected intravenously (i.v.). Nec-1s (100 mM stock in DMSO) and mTNF- $\alpha$ were diluted in endotoxin-free PBS and injected in a volume of $200 \mu \mathrm{l}$, while Sorafenib was dissolved in an aqueous solution containing $8.75 \%$ ethanol and $12.5 \%$ Chremophor EL (as described earlier in Sonntag et al..$^{75}$ ) and administrated in a total volume of $200 \mu$ l. Rectal body temperature was recorded with an electric thermometer. Plasma samples were collected and cytokine (mTNF- $\alpha$ and mIL-6) concentrations were determined using a ProcartaPlex Multiplex Immunoassay (affymetrix, eBioscience) for Luminex200, according to manufacturer's protocol. Two samples reached the maximum detection limit of Luminex and were given $30000 \mathrm{pg} / \mathrm{ml}$ as concentration.

Induction of renal ischemia-reperfusion injury. All in vivo experiments were conducted according to the protocols approved by the Protection of Animals Act (kidney IRI model). For all IRI experiments, 8-week-old male C57BL/6N mice (Charles River, Sulzfeld, Germany) were used $15 \mathrm{~min}$ before the onset of ischemia, mice received Sorafenib or vehicle in given concentrations in a total volume of $200 \mu /$ via intraperitoneal injection. Following inhalative induction narcosis with isoflurane, kidney IRI was performed as described previously. ${ }^{44}$ See also Supplementary Materials and Methods.

Statistics. Two or three independent experiments were performed (as indicated in figure legends) and data were analyzed using GraphPad Prism 6. Values represent the mean values \pm standard error of the mean, unless indicated otherwise. For survival curve analysis, a Log-rank (Mantel-Cox) test was performed.
One-way ANOVA and a Bonferroni multiple comparison test was performed where indicated. Statistical significance was accepted at $P<0.05$.

FACS, quantitative PCR, clonogenic assay, synthesis biotinylated Sorafenib. See Supplementary Material and Methods.

\section{Conflict of Interest}

The authors declare no conflict of interest.

Acknowledgements. Research in the group of Professor P. Vandenabeele is supported by grants from the Vlaams Instituut voor Biotechnologie (VIB), from Ghent University (MRP, GROUP-ID consortium), a grant from the 'Foundation against Cancer' (2012-188 and FAF-F/2016/865), grants from the Fonds voor Wetenschappelijk Onderzoek Vlaanderen (FWO) (FWO G.0875.11, FWO G.0A45.12N, FWO G.0787.13N, FWO G.0E04.16N), grants from the Flemish Government (Methusalem BOF09/01M00709 and BOF16/MET_V/007), a grant from the Belgian science policy office (BELSPO)(IAP 7/32). SM was supported by the 'Institute for the promotion of Innovation by Science and Technology in Flanders' (IWT). We thank Stephanie Kourula and Divert Tatyana for their help with the TNF-induced SIRS model, Ria Roelandt for providing recombinant kinase material and Jolien Bridelance for providing the L929sAhFas MLKL-/- inducible mMLKL-Flag and mMLKL-S345D-Flag cells. Research in the Linkermann laboratory is supported by the German Research Foundation (DFG) in the cluster of excellence 'Inflammation at Interfaces', EXC306. Research in the Fulda group is supported by grants from the Deutsche Forschungsgemeinschaft, the European Union's Horizon 2020 research and innovation program under the Marie Sklodowska-Curie grant agreement No 675448, BMBF and IUAP VII. This research was supported by a grant from the National Research Foundation of Korea (NRF) funded by the Ministry of Science, ICT and Future Planning (NRF-2015R1A3A2066581) (to J. Song).

1. Festjens N, Vanden Berghe T, Vandenabeele P. Necrosis, a well-orchestrated form of cell demise: signalling cascades, important mediators and concomitant immune response. Biochim Biophys Acta 2006; 1757: 1371-1387.

2. Pasparakis M, Vandenabeele P. Necroptosis and its role in inflammation. Nature 2015; 517 : 311-320.

3. Hanahan D, Weinberg RA. Hallmarks of cancer: the next generation. Cell 2011; 144: 646-674.

4. Kaczmarek A, Vandenabeele P, Krysko DV. Necroptosis: the release of damage-associated molecular patterns and its physiological relevance. Immunity 2013; 38: 209-223.

5. Degterev A, Hitomi J, Germscheid M, Ch'en IL, Korkina O, Teng X et al. Identification of RIP1 kinase as a specific cellular target of necrostatins. Nat Chem Biol 2008; 4 : 313-321.

6. Cho YS, Challa S, Moquin D, Genga R, Ray TD, Guildford M et al. Phosphorylation-driven assembly of the RIP1-RIP3 complex regulates programmed necrosis and virus-induced inflammation. Cell 2009; 137: 1112-1123.

7. He S, Wang L, Miao L, Wang T, Du F, Zhao L et al. Receptor interacting protein kinase-3 determines cellular necrotic response to TNF-alpha. Cell 2009; 137: 1100-1111.

8. Zhang DW, Shao J, Lin J, Zhang N, Lu BJ, Lin SC et al. RIP3, an energy metabolism regulator that switches TNF-induced cell death from apoptosis to necrosis. Science 2009; 325: 332-336.

9. Newton K, Dugger DL, Wickliffe KE, Kapoor N, de Almagro MC, Vucic D et al. Activity of protein kinase RIPK3 determines whether cells die by necroptosis or apoptosis. Science 2014; 343: 1357-1360.

10. Vandenabeele P, Galluzzi L, Vanden Berghe T, Kroemer G. Molecular mechanisms of necroptosis: an ordered cellular explosion. Nat Rev Mol Cell Biol 2010; 11: 700-714.

11. Micheau O, Tschopp J. Induction of TNF receptor I-mediated apoptosis via two sequential signaling complexes. Cell 2003; 114: 181-190.

12. Ea CK, Deng L, Xia ZP, Pineda G, Chen ZJ. Activation of IKK by TNFalpha requires sitespecific ubiquitination of RIP1 and polyubiquitin binding by NEMO. Mol Cell 2006; 22: 245-257.

13. Dondelinger Y, Jouan-Lanhouet S, Divert T, Theatre E, Bertin J, Gough PJ et al. NF-kappaBindependent role of IKKalpha/IKKbeta in preventing RIPK1 kinase-dependent apoptotic and necroptotic cell death during TNF signaling. Mol Cell 2015; 60: 63-76.

14. Vercammen D, Beyaert R, Denecker G, Goossens V, Van Loo G, Declercq W et al. Inhibition of caspases increases the sensitivity of L929 cells to necrosis mediated by tumor necrosis factor. J Exp Med 1998; 187: 1477-1485.

15. Kaiser WJ, Upton JW, Long AB, Livingston-Rosanoff D, Daley-Bauer LP, Hakem R et al. RIP3 mediates the embryonic lethality of caspase-8-deficient mice. Nature 2011; 471 : 368-372.

16. Oberst A, Dillon CP, Weinlich R, McCormick LL, Fitzgerald P, Pop C et al. Catalytic activity of the caspase-8-FLIP(L) complex inhibits RIPK3-dependent necrosis. Nature 2011; 471: 363-367. 
17. Welz PS, Wullaert A, Vlantis K, Kondylis V, Fernandez-Majada V, Ermolaeva $M$ et al. FADD prevents RIP3-mediated epithelial cell necrosis and chronic intestinal inflammation. Nature 2011; 477: 330-334.

18. Wang H, Sun L, Su L, Rizo J, Liu L, Wang LF et al. Mixed lineage kinase domain-like protein MLKL causes necrotic membrane disruption upon phosphorylation by RIP3. Mol Cell 2014; 54: 133-146.

19. Dondelinger Y, Declercq W, Montessuit S, Roelandt R, Goncalves A, Bruggeman I et al. MLKL compromises plasma membrane integrity by binding to phosphatidylinositol phosphates. Cell Rep 2014; 7: 971-981.

20. Cai Z, Jitkaew S, Zhao J, Chiang HC, Choksi S, Liu J et al. Plasma membrane translocation of trimerized MLKL protein is required for TNF-induced necroptosis. Nat Cell Biol 2014; 16: $55-65$.

21. Chen X, Li W, Ren J, Huang D, He WT, Song Y et al. Translocation of mixed lineage kinase domain-like protein to plasma membrane leads to necrotic cell death. Cell Res 2014; 24: 105-121.

22. Degterev A, Huang Z, Boyce M, Li Y, Jagtap P, Mizushima N et al. Chemical inhibitor of nonapoptotic cell death with therapeutic potential for ischemic brain injury. Nat Chem Biol 2005; 1: 112-119.

23. Amantini C, Morelli MB, Santoni M, Soriani A, Cardinali C, Farfariello V et al. Sorafenib induces cathepsin B-mediated apoptosis of bladder cancer cells by regulating the Akt/PTEN pathway. The Akt inhibitor, perifosine, enhances the sorafenib-induced cytotoxicity against bladder cancer cells. Oncoscience 2015; 2: 395-409.

24. Broecker-Preuss M, Muller S, Britten M, Worm K, Schmid KW, Mann K et al. Sorafenib inhibits intracellular signaling pathways and induces cell cycle arrest and cell death in thyroid carcinoma cells irrespective of histological origin or BRAF mutational status. BMC Cancer 2015; $15: 184$.

25. Ramirez-Labrada A, Lopez-Royuela N, Jarauta V, Galan-Malo P, Azaceta G, Palomera L et al. Two death pathways induced by sorafenib in myeloma cells: Puma-mediated apoptosis and necroptosis. Clin Transl Oncol 2015; 17: 121-132.

26. Wilhelm S, Carter C, Lynch M, Lowinger T, Dumas J, Smith RA et al. Discovery and development of sorafenib: a multikinase inhibitor for treating cancer. Nat Rev Drug Discov 2006; 5: 835-844.

27. Pemmaraju N, Kantarjian H, Andreeff M, Cortes J, Ravandi F. Investigational FMS-like tyrosine kinase 3 inhibitors in treatment of acute myeloid leukemia. Expert Opin Investig Drugs 2014; 23: 943-954.

28. Wilhelm SM, Carter C, Tang L, Wilkie D, McNabola A, Rong H et al. BAY 43-9006 exhibits broad spectrum oral antitumor activity and targets the RAF/MEK/ERK pathway and receptor tyrosine kinases involved in tumor progression and angiogenesis. Cancer Res 2004; 64: 7099-7109.

29. Wilhelm SM, Adnane L, Newell P, Villanueva A, Llovet JM, Lynch M. Preclinical overview of sorafenib, a multikinase inhibitor that targets both Raf and VEGF and PDGF receptor tyrosine kinase signaling. Mol Cancer Ther 2008; 7: 3129-3140.

30. Rahmani M, Davis EM, Crabtree TR, Habibi JR, Nguyen TK, Dent P et al. The kinase inhibitor sorafenib induces cell death through a process involving induction of endoplasmic reticulum stress. Mol Cell Biol 2007; 27: 5499-5513.

31. Prieto-Dominguez N, Ordonez R, Fernandez A, Garcia-Palomo A, Muntane J, GonzalezGallego $\mathrm{J}$ et al. Modulation of autophagy by Sorafenib: effects on treatment response. Front Pharmacol 2016; 7: 151.

32. Dondelinger Y, Aguileta MA, Goossens V, Dubuisson C, Grootjans S, Dejardin E et al. RIPK3 contributes to TNFR1-mediated RIPK1 kinase-dependent apoptosis in conditions of clAP1/2 depletion or TAK1 kinase inhibition. Cell Death Differ 2013; 20: 1381-1392.

33. Fauster A, Rebsamen M, Huber KV, Bigenzahn JW, Stukalov A, Lardeau CH et al. A cellular screen identifies ponatinib and pazopanib as inhibitors of necroptosis. Cell Death Dis 2015; 6: e1767.

34. Safferthal C, Rohde K, Fulda S. Therapeutic targeting of necroptosis by Smac mimetic bypasses apoptosis resistance in acute myeloid leukemia cells. Oncogene 2017; 36: 1487-1502.

35. Gilmore TD. Introduction to NF-kappaB: players, pathways, perspectives. Oncogene 2006; 25: 6680-6684.

36. Pahl HL. Activators and target genes of Rel/NF-kappaB transcription factors. Oncogene 1999; 18: 6853-6866.

37. Vanden Berghe T, Kalai M, van Loo G, Declercq W, Vandenabeele P. Disruption of HSP90 function reverts tumor necrosis factor-induced necrosis to apoptosis. J Biol Chem 2003; 278: $5622-5629$

38. Li D, Xu T, Cao Y, Wang H, Li L, Chen $\mathrm{S}$ et al. A cytosolic heat shock protein 90 and cochaperone CDC37 complex is required for RIP3 activation during necroptosis. Proc Natl Acad Sci USA 2015; 112: 5017-5022

39. Jacobsen AV, Lowes KN, Tanzer MC, Lucet IS, Hildebrand JM, Petrie EJ et al. HSP90 activity is required for MLKL oligomerisation and membrane translocation and the induction of necroptotic cell death. Cell Death Dis 2016; 7: e2051.

40. Allen JJ, Li M, Brinkworth CS, Paulson JL, Wang D, Hubner A et al. A semisynthetic epitope for kinase substrates. Nat Methods 2007; 4: 511-516.

41. Sanghera J, Li R, Yan J. Comparison of the luminescent ADP-Glo assay to a standard radiometric assay for measurement of protein kinase activity. Assay Drug Dev Technol 2009; 7: 615-622.

42. Duprez L, Takahashi N, Van Hauwermeiren F, Vandendriessche B, Goossens V, Vanden Berghe $T$ et al. RIP kinase-dependent necrosis drives lethal systemic inflammatory response syndrome. Immunity 2011; 35: 908-918.
43. Newton K, Dugger DL, Maltzman A, Greve JM, Hedehus M, Martin-McNulty B et al. RIPK3 deficiency or catalytically inactive RIPK1 provides greater benefit than MLKL deficiency in mouse models of inflammation and tissue injury. Cell Death Differ 2016; 23: 1565-1576.

44. Linkermann A, Brasen JH, Himmerkus N, Liu S, Huber TB, Kunzendorf U et al. Rip1 (receptor-interacting protein kinase 1) mediates necroptosis and contributes to renal ischemia/reperfusion injury. Kidney Int 2012; 81: 751-761.

45. Linkermann A, Brasen JH, Darding M, Jin MK, Sanz AB, Heller JO et al. Two independent pathways of regulated necrosis mediate ischemia-reperfusion injury. Proc Natl Acad Sci USA 2013; 110: 12024-12029.

46. Park JG. Long-term outcomes of patients with advanced hepatocellular carcinoma who achieved complete remission after sorafenib therapy. Clin Mol Hepatol 2015; 21: 287-294.

47. Escudier B, Eisen T, Stadler WM, Szczylik C, Oudard S, Staehler M et al. Sorafenib for treatment of renal cell carcinoma: Final efficacy and safety results of the phase III treatment approaches in renal cancer global evaluation trial. J Clin Oncol 2009; 27: 3312-3318.

48. Harris PA, Bandyopadhyay D, Berger SB, Campobasso N, Capriotti CA, Cox JA et al. Discovery of small molecule RIP1 kinase inhibitors for the treatment of pathologies associated with necroptosis. ACS Med Chem Lett 2013; 4: 1238-1243.

49. Mandal P, Berger SB, Pillay S, Moriwaki K, Huang C, Guo H et al. RIP3 induces apoptosis independent of pronecrotic kinase activity. Mol cell 2014; 56: 481-495.

50. Sun L, Wang H, Wang Z, He S, Chen S, Liao D et al. Mixed lineage kinase domain-like protein mediates necrosis signaling downstream of RIP3 kinase. Cell 2012; 148: 213-227

51. Hildebrand JM, Tanzer MC, Lucet IS, Young SN, Spall SK, Sharma P et al. Activation of the pseudokinase MLKL unleashes the four-helix bundle domain to induce membrane localization and necroptotic cell death. Proc Natl Acad Sci USA 2014; 111: 15072-15077.

52. Vanden Berghe $T$, Linkermann $A$, Jouan-Lanhouet $S$, Walczak $H$, Vandenabeele $P$. Regulated necrosis: the expanding network of non-apoptotic cell death pathways. Nat Rev Mol Cell Biol 2014; 15: 135-147.

53. Degterev A, Linkermann A. Generation of small molecules to interfere with regulated necrosis. Cell Mol Life Sci 2016; 73: 2251-2267.

54. Najjar M, Suebsuwong C, Ray SS, Thapa RJ, Maki JL, Nogusa S et al. Structure guided design of potent and selective ponatinib-based hybrid inhibitors for RIPK1. Cell Rep 2015; 10: $1850-1860$.

55. Li JX, Feng JM, Wang Y, Li XH, Chen XX, Su Y et al. The B-Raf(V600E) inhibitor dabrafenib selectively inhibits RIP3 and alleviates acetaminophen-induced liver injury. Cell Death Dis 2014; 5: e1278.

56. Xie T, Peng W, Liu Y, Yan C, Maki J, Degterev A et al. Structural basis of RIP1 inhibition by necrostatins. Structure 2013; 21: 493-499.

57. Wan PT, Garnett MJ, Roe SM, Lee S, Niculescu-Duvaz D, Good VM et al. Mechanism of activation of the RAF-ERK signaling pathway by oncogenic mutations of B-RAF. Cell 2004; 116: 855-867.

58. Strumberg D. Sorafenib for the treatment of renal cancer. Expert Opin Pharmacother 2012; 13: 407-419

59. Linkermann A, Stockwell BR, Krautwald S, Anders HJ. Regulated cell death and inflammation: an auto-amplification loop causes organ failure. Nat Rev 2014; 14: 759-767.

60. Himmelsbach K, Sauter D, Baumert TF, Ludwig L, Blum HE, Hildt E. New aspects of an anti-tumour drug: sorafenib efficiently inhibits HCV replication. Gut 2009; 58: 1644-1653.

61. Benedict A, Bansal N, Senina S, Hooper I, Lundberg L, de la Fuente C et al. Repurposing FDA-approved drugs as therapeutics to treat Rift Valley fever virus infection. Front Microbiol 2015; 6: 676.

62. Yang YY, Huang YT, Lee TY, Chan CC, Yeh YC, Lee KC et al. Rho-kinasedependent pathway mediates the hepatoprotective effects of sorafenib against ischemia/ reperfusion liver injury in rats with nonalcoholic steatohepatitis. Liver Transp/ 2012; 18 : 1371-1383.

63. Liu JY, Park SH, Morisseau C, Hwang SH, Hammock BD, Weiss RH. Sorafenib has soluble epoxide hydrolase inhibitory activity, which contributes to its effect profile in vivo. Mol Cancer Ther 2009; 8: 2193-2203.

64. Echeverria V, Burgess S, Gamble-George J, Zeitlin R, Lin X, Cao C et al. Sorafenib inhibits nuclear factor kappa B, decreases inducible nitric oxide synthase and cyclooxygenase-2 expression, and restores working memory in APPswe mice. Neuroscience 2009; 162 : $1220-1231$.

65. Capece D, Fischietti M, Verzella D, Gaggiano A, Cicciarelli G, Tessitore A et al. The inflammatory microenvironment in hepatocellular carcinoma: a pivotal role for tumorassociated macrophages. Biomed Res Int 2013; 2013: 187204.

66. Castello G, Scala S, Palmieri G, Curley SA, Izzo F. HCV-related hepatocellular carcinoma: from chronic inflammation to cancer. Clin Immunol 2010; 134: 237-250.

67. Strilic B, Yang L, Albarran-Juarez J, Wachsmuth L, Han K, Muller UC et al. Tumour-cellinduced endothelial cell necroptosis via death receptor 6 promotes metastasis. Nature 2016; 536: 215-218.

68. Liu X, Zhou M, Mei L, Ruan J, Hu Q, Peng J et al. Key roles of necroptotic factors in promoting tumor growth. Oncotarget 2016; 7: 22219-22233.

69. Ashburn TT, Thor KB. Drug repositioning: identifying and developing new uses for existing drugs. Nat Rev Drug Discov 2004; 3: 673-683.

70. Strittmatter SM. Overcoming drug development bottlenecks with repurposing: old drugs learn new tricks. Nat Med 2014; 20: 590-591. 
71. Steinhart L, Belz K, Fulda S. Smac mimetic and demethylating agents synergistically trigger cell death in acute myeloid leukemia cells and overcome apoptosis resistance by inducing necroptosis. Cell Death Dis 2013; 4: e802.

72. Steinwascher S, Nugues AL, Schoeneberger H, Fulda S. Identification of a novel synergistic induction of cell death by Smac mimetic and HDAC inhibitors in acute myeloid leukemia cells. Cancer Lett 2015; 366: 32-43.

73. Vanden Berghe T, Grootjans S, Goossens V, Dondelinger Y, Krysko DV, Takahashi N et al. Determination of apoptotic and necrotic cell death in vitro and in vivo. Methods 2013; 61 117-129.

74. Takahashi N, Duprez L, Grootjans S, Cauwels A, Nerinckx W, DuHadaway JB et al. Necrostatin-1 analogues: critical issues on the specificity, activity and in vivo use in experimental disease models. Cell Death Dis 2012; 3: e437.

75. Sonntag R, Gassler N, Bangen JM, Trautwein C, Liedtke C. Pro-apoptotic Sorafenib signaling in murine hepatocytes depends on malignancy and is associated with PUMA expression in vitro and in vivo. Cell Death Dis 2014; 5: e1030. (c) (i) Cell Death and Disease is an open-access journal published by Nature Publishing Group. This work is licensed under a Creative Commons Attribution 4.0 International License. The images or other third party material in this article are included in the article's Creative Commons license, unless indicated otherwise in the credit line; if the material is not included under the Creative Commons license, users will need to obtain permission from the license holder to reproduce the material. To view a copy of this license, visit http://creativecommons.org/licenses/by/4.0/

(C) The Author(s) 2017

Supplementary Information accompanies this paper on Cell Death and Disease website (http://www.nature.com/cddis) 